DOI https://doi.org/10.18551/rjoas.2017-03.08

\title{
THE IMPACT OF FUNDING SOURCES, OWNERSHIP STRUCTURE, DIVERSFICATION, EXTERNAL FACTOR ON DIVIDEND, INVESTMENT, AND FIRM VALUE
}

\author{
Darmawan Ari \\ Faculty of Administrative Science, University of Brawijaya, Indonesia \\ E-mail: aridarmawan.fia.ub@gmail.com
}

\begin{abstract}
This research was motivated to reexamine; a) debate the superiority of dividends and investment in creating firm value, and b) the factors that affect the dividend, investment, firm value. This study examines the firm that has been listed in Indonesia Stock Exchange from 2004 until 2008. The results of this study found indications of dividends and investment are factors that can increase the value of the firm, although such dividends to be superior compared with investments in companies in creating value.
\end{abstract}

\section{KEY WORDS}

Source of financing, ownership structure, diversification, external factors, dividend, investment, firm value.

The impact of dividend and investment to the firm value has caused the debate. In 1961, Miller and Modigliani with its dividend irrelevance theory, stated that dividend has not influence to the firm and investment that becomes important factor to create firm value, caused debate more four decades. This debate appears because of Miller and Modigliani theory is different from Bird-in-the-Hand-Theory. The existing of debate, Black (1976), mentioned as dividend puzzle, stated that "the harder we look at the dividend picture, the more it seems like a puzzle, with pieces that just don't fix together". There are more questions, that stated by Black (1976) but the important question that may until now has not answered yet such a a) why do corporations pay dividend? and b) why do investors pay attention to dividend?

The questions from Black (1976) are attempted to answer by some researchers. Feldstein and Green (1983) stated that the firm pays dividend because of fulfillment or accommodating: a) preference shareholders for their taxes, and b) the tendency of shareholder to make portfolio of his investment to face the uncertainty. Bortz and Rust (1984) that develop the thought by Feldstein and Green (1983) stated that important dividend for investor to balance the risk and return from portfolio that is owned by investor.

Besides Feldstein and Green (1979); Bortz and Rust (1984), there are several argumentations to answer why the firm pays the dividend. Bhattacharyya (1979) with dividend signaling model, stated that by existing information asymmetry between company and shareholder (investor), dividend is used as mechanism to give information for investor. Other thought that based on the point of view of investor preference is clientele effect (MM). The consequences of this thought are a) the firm has determined certain dividend paying policy, which then attract attention from "clientele" that consists of investor who likes dividend policy (Brigham, 1995), and b) the difference of tax rate between capital gain and dividend may directs to the tendency for each company to attract attention of "clientele" that consists of investors tend to like the dividend payment (Levy and Sarnat, 1994). According to Black (1976), there are several types of investors, i.e. a) investor that likes company stock with high dividend yield, b) investor that likes return which derives from dividend and capital gains, and c) investor that likes the firm stock with low dividend yield. The implication of the thought from dividend signaling model (Bhattacharyya, 1979), clientele effect (MM), are shareholders (investors) will consider the dividend is an important factor in order to enhance firm value.

There are some other ideas that are based on the agency relationship, i.e. Monitoring Hypothesis (Easterbrook, 1984), and Free Cash Flow Hypothesis (Jensen, 1986). Both ideas 
viewed dividend can be used as the tool or mechanism to oversee the actions of the firm manager with the aim of all the decisions of the firm managers in accordance with the interests of shareholders. The expected implication from both ideas is the firm with low agency problem will cause low agency cost, so it will improve the firm value. There are other ideas that discussed the role of dividends, although it does not strengthen the ideas of Monitoring Hypothesis, Free Cash Flow Hypothesis, namely: Tax Preference Theory, and Residual Dividend Theory. Both of these ideas considers that the firm that pays dividend will decrease the firm value because the existing of different tax, and reduced the proportion of retained earnings are used to fund the firm investment.

Some ideas have been trying to decipher the debate dividend relationship on firm value, although that debate has not solved yet recently. It looks like the argument of Black (1976) is valid until now. Brealey and Myers (1991) also suggested one of the problems that has not solved yet recently is the debate about dividend payment. The empirical finding that is concluded by Frankfurter and Wood (2002), Bhattacharya (2007) showed the different empirical finding.

The second debate in this research is the debate about the relation between dividend and investment. This debate comes from the inappropriate argumentation in one assumption from Dividend Irrelevance Theory (MM) that stated the assumption of the firm has determined in advance of the investment and the debt will be made by the firm that has caused some consequences. First, dividend policy of company is not influenced by funding policy and investment policy. If the firm wants to increase dividend payments without affecting the investment policy and funding policy that has defined the firm, so to meet the funds used to pay a dividend is by issuing new shares. Second, if the investment company has been set previously, the firm value is consistent. Based on the Dividend Irrelevance Theory, the only determinant of importance of the value of the firm is a firm investment decisions, due to the firm investment is considered to increase the firm profitability in the future. This argumentation is strengthened of research result by Morck, Shleifer and Vishny (1988), which found evidence of R\&D have a significantly positive effect on profitability. The viewpoint that considers the investment more important than the dividend, then Dunham (2008) mentions the investment decision is a first-order decision value and dividend decision is a second-order value decision for the dividend decision was made after the investment decision has been set.

The debate that has been described previously, have motivated researchers to reexamine the Miller and Modigliani ideas, that indicates: a) the dividend policy does not influence the firm investment policy, b) investment is more superior than dividend in creating the firm value, and c) the payment of dividend does not influence the firm investment.

\section{THEORETICAL FRAMEWORK}

The source of funding can affect the dividend policy, investment policy, and firm value. The firm that has good profitability will have better ability to fund the dividend payment and firm investment. If the firm get lack of fund to fund the payment of dividend and firm investment, so the firm will get to use external fund source through the using of leverage. According to the thought of packing order theory, leverage is the main priority of external funding source than publishing new security. Besides that, the firm tends to do not publish new security to avoid dilution, and this matter can decrease the firm value. The using of leverage by company, caused importance conflict between manager and company investor. Manager tends to use low leverage because a) manager attempts to avoid the risk to sustain the prosperity and its position in company, and b) manager attempts to control the policy of dividend and investment policy is still strong under company manager tan the creditor. The effort to sustain the dividend policy and investment policy are by maximizing the internal funding source of company.

According to the ideas of debt covenant hypothesis (Kalay, 1982), the firm that uses high leverage will cause the firm has no good ability to pay dividend. Related to the investment policy, Aivazian et al. (2005) expressed that the firm that uses high leverage 
causes the firm cannot maximize to fund the whole investment opportunity that has been owned by company (under investment problem). The effect of under investment problem is the increasing FCF that has been owned by company. Theoretically, (free cash flow hypothesis), the firm that has high FCF, I will to have potential to cause over investment problem and agency problem. In other words, the shareholders of company attempt to encourage the manager to use high leverage with the motive a) the risk transfer of shareholder to the creditor, and b) the prosperity transfer from creditor to the shareholder.

The using of leverage can give the influence to profitability. The first aim of company to use leverage is to fulfill the lack of funding source and to increase the profitability of company. If the firm has no good work ability so the use of high leverage will decrease profitability of company. Interaction from: leverage, FCF, profitability, the ownership of manager security, and ownership of institution security to dividend policy and investment policy will influence the dividend amount and company investment and finally be able to influence the firm value.

This research also does examine of others factors that may influence dividend and investment, i.e. diversification and external factor of company. Diversification has the important role in deciding dividend policy and investment policy of company. There are some reasons that strengthen this argument. Firstly, the firm that do diversification generally is the big company (Chen and Ho, 2000; Mackey 2006; Fan, et al., 2008), and the firm tends to pay dividend in high amount (DeAngelo et al., 2006; Bulan et al., 2007; Renneboog, and Trojanowski, 2007; Denis and Osobov, 2008). Second, the diversified firm also requires substantial funds to finance new investment projects or reinvested in the business segment that already exist (Doukas and Pentzalis, 2003; Tong, 2009). This argumentation motivates the researcher to know the influence the diversification to the dividend, investment.

The influence of external factors on dividend policy and investment policy is based on several arguments. First, external factors will have a negative impact on the use of leverage (Hu, 1999; Ooi, 1999; Cheng and Shiu, 2007; Kandir 2008). The implication that appears with high monetary capital from leverage is the firm has no wideness to fund investment project. Secondly, external factor will give negative effect on return that will be received by company and investor (Nelson, 1976; Barnes et al., 1999). Tsoukalas and Sil (1999) found that the evidence of negative relationship between external factor (inflation) and the security price of company. The height of inflation level and monetary interest earning will cause investor be prefer to save money in bank than buying security. Thirdly, external factor will give the effect in decreasing of company productivity (Elder, 2004), which finally having negative influence between external factor (inflation) and economic growth.

If refer to the research by Dhrymes and Kurz (1967), Jensen et al. (1976), McCabe (1979), Peterson and Benesh (1983), Elston (1996), Adedeji (1998), Gugler (2003), that indicate dividend and investment are influenced each other, external factor has the influence to investment, so it ca be predicted that external factor will has the influence to dividend. The research that found indication of external factor has the influence to firm investment are McCabe (1979), Bleaney (1996), Hu (1999), London and Smith (2008).

The existing of company productivity and low economic growth will give negative impact to investment policy and dividend policy of company. The firm which experienced a decline in financial performance, so the firm tends to pay dividend in low amount or even the firm does not pay the dividend. The existing of inflation level and monetary interest earning, causes the firm consider to neither delay nor even cancel of investment project that will be conducted. It is due to high monetary fund used to fund investment project. High foreign money value can cause the production cost is high.

The influence of external factor to dividend policy is based on the argumentation by Marsh and Merton (1987) stated that research model concerning dividend generally focuses on micro behavior in company. The existing of examining of external factor influence to dividend is expected to give contribution in theory about dividend which does not include external factor as the factor that influences dividend policy of company.

Related to firm value, this research is also motivated to examine the argumentation from MM. In addition, the existing of point of view that the aim of company is to maximize the 
market value of company. Thus it cases the creating of firm value becomes one of interesting subject for academia and practitioners in last decade (López-Iturriaga and Rodríguez-Sanz, 2001). Argumentation from MM has stated that the firm has considered about investment and loan that will be conducted by company. It indicates the dividend policy is not influenced by funding policy and investment policy of company. The consequence of this assumption is if the firm wants to heighten dividend that is divided to shareholders which is not changing or affecting investment policy and funding policy that are decided by company. To fulfill the fund used by company to pay dividend is by publishing new security. The basic argumentation of MM stated that dividend is not relevant to firm value, that is caused investor tends to pay attention return total from firm investment and tends to do not care whether return comes from dividend or capital gain.

If the point at research findings, it is predicted that dividend and investment can affect firm value, even though the theory that is explained the relationship between dividend, investment, to firm value, now it still becomes the debate. In empirical side, it is much more the research to examine those theory and those research finding are failed to explain the strong support in theory because of the research finding are differ each other.

The research finding in a lot, it tends to strengthen argumentation that dividend can affect firm value. The research by Rees (1999), Barker (1999), Riahi-Belkaoui, and Picur (2001), Ghosh (2007), Sulong and Noor (2008), Hughes (2008), found that the dividend has significant influence with positive direction to the firm value.

On the other hand, there are some researches to be doubtful that dividend is important because it can affect firm value. Stevens and Jose (1992); Allen and Rachim (1996), found that indication of negative relationship between dividend and firm value. Watts (1973), Penman (1983), Benartzi et al. (1997), Conroy et al. (2000), DeAngelo et al. (2000), Grullon et al. (2002), Grullon et al. (2005), Blau and Fuller (2008), found that doubted on dividend indication has information about good prospect from company in the future. The interesting finding from the research by Fama and French (2001) found that company indication registered in New York Stock Exchange, American Stock Exchange, and NASDAQ since 1978-1999 that get decrease of dividend cost from $65 \%$ to $20,8 \%$. This finding has indicated that the dividend thought can be used to improve firm value has caused the doubtfulness.

On other hand, investment has positive influence to firm value (strengthened argument by MM), Morck et al.(1988), Cho (1998); López-Iturriaga and Rodríguez-Sanz (2001); Del Brio et al. (2003); Connolly and Hirschey (2005), i.e. investment has significant influence with the negative relationship to firm value.

This research also examines other factors that can influence firm value. Some findings of previous studies have indicated that there are other factors that influence firm value. For this importance, this research also do examine between funding source, security ownership structure, diversification, external factor to firm value. Funding source and ownership structure are the fundamental factors of company. The composition of funding source and ownership structure on company security will have the influence to firm value. Related to diversification, there is a debate whether diversification will decrease the firm value (diversification discount hypothesis) or diversification will improve the firm value (diversification premium hypothesis). External factor also has the important influence to the firm value because related to systematic of company. The higher external factors (like inflation, monetary interest earning, and exchange value of foreign money) will have negative influence for investment. If pointing at the ideas by $\mathrm{MM}$, the firm that funds the investment in low amount will decrease the firm value.

This research examines a) the factors that influences dividend, investment, firm value, b) dividend for investment, c) dividend and investment to firm value, in the context of companies that be "go public" in Indonesia. The aim is to examine the theory in country context that is developed like Indonesia. The theories and previous studies describe the condition of the companies in progress countries like US and UK. This research focuses on examining the actors that influence dividend, investment, and firm value in the companies of developed countries 
This argumentation points at the statement by Kang (2001) that states the firm that exist in different countries may will follow different dividend policy because the difference in economy macro, economic development, tax system, corporate governance system, and other institution factor . the result of research that strengthen the argumentation by Kang (2001) is the research that is conducted by Glen et al. (1995); Adouglu (2000), Kang (2000), Aivazian et al. (2003a,b); Rahman (2006); Brown et al. (2008), that found the indication which there are difference of dividend policy between the companies in progress country and developed country.

The thought by Kang (2001) that indicates the existing of differences on dividend policy, it may the existing investment policy in the firm of progress country and developed country. Argumentation that becomes the basis is a)the result of previous studies that indicates the dividend and investment policy that have influenced each other (like Dhrymes and Kurz, 1967; Peterson and Benesh 1983; Adedeji, 1998; Gugler 2003; Brav et al., 2005; Dunham, 2008) and b) dividend policy differences on companies in developed countries and in developing countries (Glen et al., 1995; Adaoglu, 2000; Kang, 2001; Aivazian et al., 2003a,b; Rahman, 2006). If pointing at both points so it shows the existing of different indication of investment policy of company in progress country and developed country. The difference of dividend policy and investment policy of company in progress country and developed country will influence the firm value.

\section{METHODS OF RESEARCH}

Research Sample. Population in this sample is the whole manufactured companies that go public in Indonesia Stock Exchange (IDX) for period 2004-2008. The research sample focuses on the firm that fulfill the criteria of company that publishes the financial statement continuously in the period 2004 to 2008 , so the sample amount in the research amounts 126 companies.

Research Variable. The research variable and research variable measurement used in this research are explained in Table 1.

Table 1 - Research Variables

\begin{tabular}{|c|l|l|}
\hline No & \multicolumn{1}{|c|}{ Construct Variable } & \\
\hline \multirow{2}{*}{1} & \multirow{2}{*}{ Funding sources } & Leverage (TDTA) \\
\cline { 3 - 3 } & & Free Cash Flow \\
\cline { 3 - 3 } & & Profitability (ROE) \\
\hline \multirow{2}{*}{2} & \multirow{2}{*}{ Ownership Structure } & Managerial Ownership \\
\cline { 3 - 3 } & & Institutional Ownership \\
\hline 3 & Diversification & Sales-based Herfindahl index \\
\hline \multirow{2}{*}{4} & \multirow{3}{*}{ External factors } & Inflation \\
\cline { 3 - 3 } & & Interest rate \\
\cline { 3 - 3 } & & Exchange rate \\
\hline 5 & Dividend & Dividend/Asset \\
\hline \multirow{2}{*}{7} & \multirow{2}{*}{ Firm value } & Investment/Asset \\
\hline & & Stock Returns \\
\cline { 3 - 3 } & & Market to Book Value of Equity \\
\cline { 3 - 3 } & & Tobin q \\
\hline
\end{tabular}

Hypothesis. The whole hypothesis used in this research is concluded in table 2 and Figure 1, as followed: 
Table 2 - Summary of Results (direct effect)

\begin{tabular}{|l|l|l|l|l|}
\hline $\mathrm{n} / \mathrm{n}$ & \multicolumn{1}{|c|}{ Hypothesis } & Coefficient & Significance & Decision \\
\hline 1 & Funding sources $\left(\mathrm{X}_{1}\right) \rightarrow$ Dividend $\left(\mathrm{Y}_{1}\right)$ & 0,133 & 0,001 & Accepted \\
\hline 2 & Ownership structure $\left(\mathrm{X}_{2}\right) \rightarrow$ Dividend $\left(\mathrm{Y}_{1}\right)$ & $-0,092$ & 0,020 & Accepted \\
\hline 3 & Funding sources $\left(\mathrm{X}_{1}\right) \rightarrow$ Investment $\left(\mathrm{Y}_{2}\right)$ & 0,622 & 0,000 & Accepted \\
\hline 4 & Ownership structure $\left(\mathrm{X}_{2}\right) \rightarrow$ Investment $\left(\mathrm{Y}_{2}\right)$ & $-0,050$ & 0,104 & Rejected \\
\hline 5 & Funding sources $\left(\mathrm{X}_{1}\right) \rightarrow$ Firm value $\left(\mathrm{Y}_{3}\right)$ & $-0,357$ & 0,000 & Accepted \\
\hline 6 & Ownership structure $\left(\mathrm{X}_{2}\right) \rightarrow$ Firm value $\left(\mathrm{Y}_{3}\right)$ & $-0,067$ & 0,059 & Rejected \\
\hline 7 & Diversification $\left(\mathrm{X}_{3}\right) \rightarrow$ Dividend $\left(\mathrm{Y}_{1}\right)$ & 0,031 & 0,437 & Rejected \\
\hline 8 & Diversification $\left(\mathrm{X}_{3}\right) \rightarrow$ Investment $\left(\mathrm{Y}_{2}\right)$ & 0,012 & 0,689 & Rejected \\
\hline 9 & Diversification $\left(\mathrm{X}_{3}\right) \rightarrow$ Firm value $\left(\mathrm{Y}_{3}\right)$ & 0,067 & 0,056 & Rejected \\
\hline 10 & External factors $\left(\mathrm{X}_{4}\right) \rightarrow$ Dividend $\left(\mathrm{Y}_{1}\right)$ & 0,010 & 0,798 & Rejected \\
\hline 11 & External factors $\left(\mathrm{X}_{3}\right) \rightarrow$ Investment $\left(\mathrm{Y}_{2}\right)$ & 0,080 & 0,009 & Accepted \\
\hline 12 & External factors $\left(\mathrm{X}_{4}\right) \rightarrow$ Firm value $\left(\mathrm{Y}_{3}\right)$ & 0,064 & 0,070 & Rejected \\
\hline 13 & Dividend $\left(\mathrm{Y}_{1}\right) \rightarrow$ Investment $\left(\mathrm{Y}_{2}\right)$ & 0,084 & 0,007 & Accepted \\
\hline 14 & Dividend $\left(\mathrm{Y}_{1}\right) \rightarrow$ Firm value $\left(\mathrm{Y}_{3}\right)$ & 0,390 & 0,000 & Accepted \\
\hline 15 & Investment $\left(\mathrm{Y}_{2}\right) \rightarrow$ Firm value $\left(\mathrm{Y}_{3}\right)$ & 0,167 & 0,000 & Accepted \\
\hline
\end{tabular}

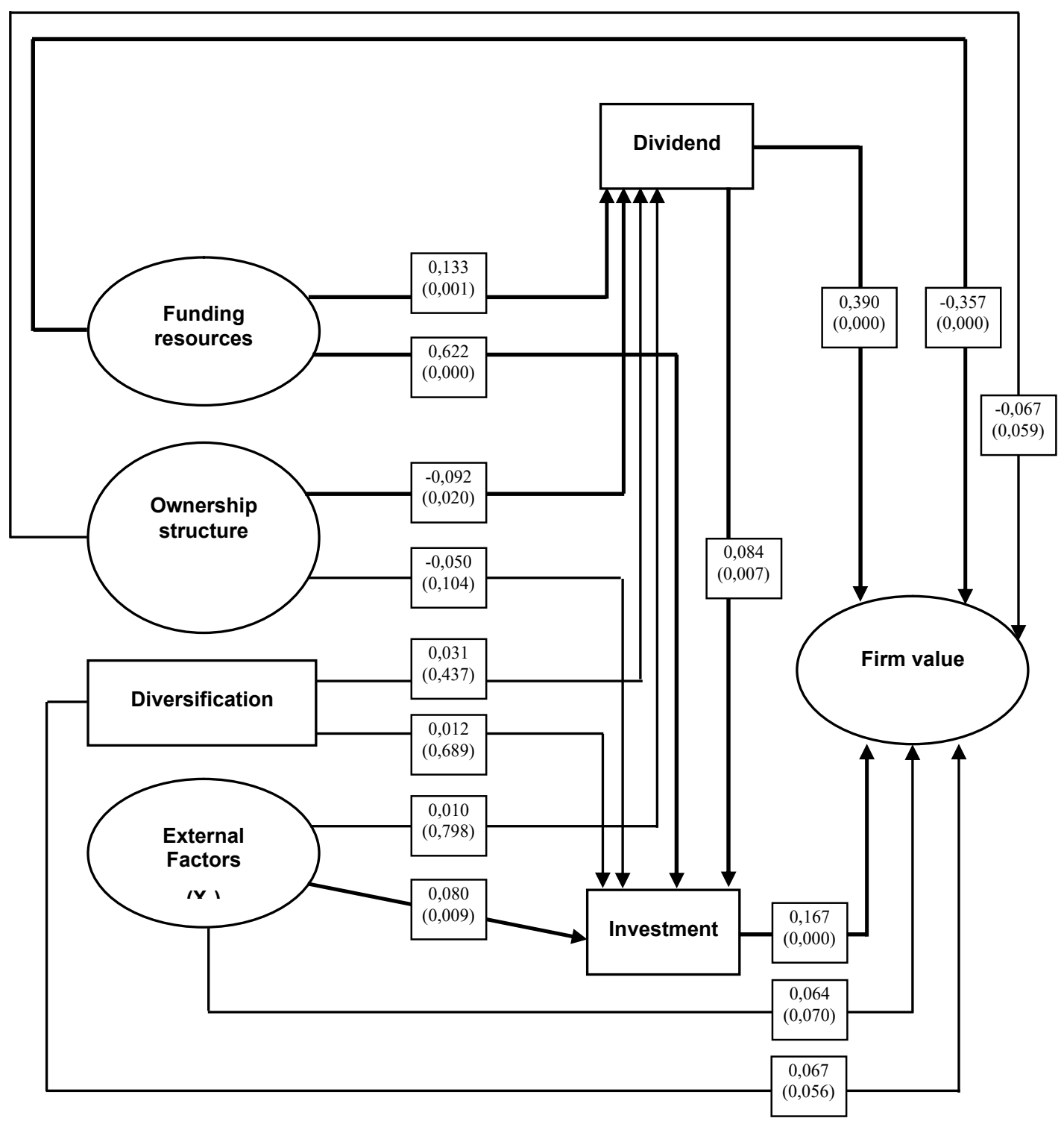

Figure 1 - Summary of Results 
Table 3 - Summary of Results (significant indirect effect)

\begin{tabular}{|c|c|c|}
\hline No. & Significant Indirect Effect & Path Coefficient \\
\hline 1 & Ownership structure $\left(\mathrm{X}_{2}\right) \rightarrow$ Dividend $\left(\mathrm{Y}_{1}\right) \rightarrow$ Firm value $\left(\mathrm{Y}_{3}\right)$ & $-0,050 \times 0,390=-0,020$ \\
\hline 2. & Funding sources $\left(\mathrm{X}_{1}\right) \rightarrow$ Dividend $\left(\mathrm{Y}_{1}\right) \rightarrow$ Investment $\left(\mathrm{Y}_{2}\right)$ & $0,133 \times 0,084=0,011$ \\
\hline 3 & Ownership structure $\left(\mathrm{X}_{2}\right) \rightarrow$ Dividend $\left(\mathrm{Y}_{1}\right) \rightarrow$ Investment $\left(\mathrm{Y}_{2}\right)$ & $-0,092 \times 0,084=-0,007$ \\
\hline 4 & External factors $\left(\mathrm{X}_{3}\right) \rightarrow$ Investment $\left(\mathrm{Y}_{2}\right) \rightarrow$ Firm value $\left(\mathrm{Y}_{3}\right)$ & $0,080 \times 0,167=0,013$ \\
\hline
\end{tabular}

DISCUSSION OF RESULTS

This research studies some influences the relation between the variable that is developed based on the ideas and argumentation from some theories. The research result gives the contribution the research result with the previous studies.

Debt Covenant Hypothesis and Under Investment Problem Hypothesis. The contribution of the research to the study contribution in the ideas of debt covenant hypothesis (Kalay, 1982) and under investment problem hypothesis (Aivazian et al., 2005) is explained in the figure 2 :

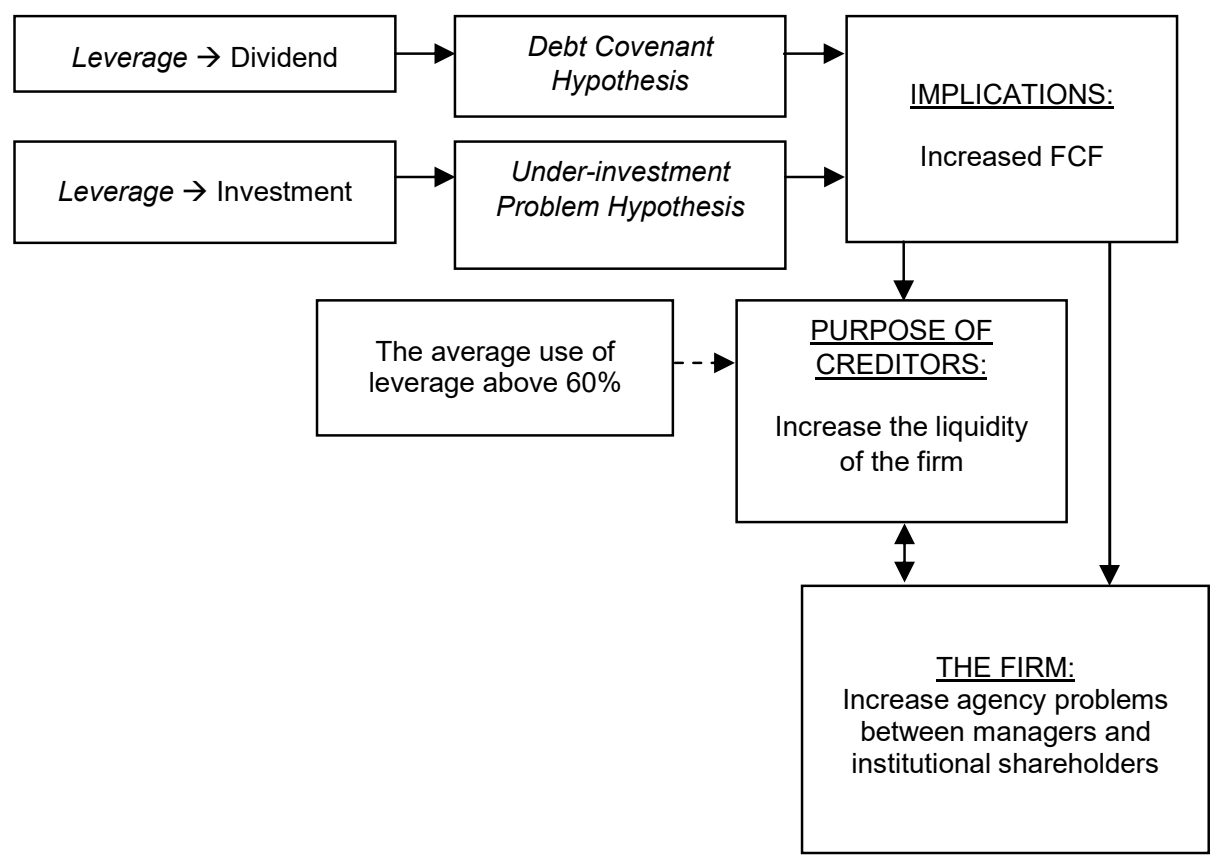

Figure 2 - Contributions Study on Debt Covenant Hypothesis and Under-investment Problem Hypothesis

Argumentations that can be explained in figure 2 as followed:

The research result found the indication of company that uses high leverage will cause the decreasing of company ability will decrease or do not pay dividend. The basic thought is the effort from creditor to avoid prosperous transfer from creditor to the investor of company.

The research result found the indication of company that uses high leverage, will cause the decreasing of company ability to maximize in funding investment, so the result is to strengthen under investment problem hypothesis, Aivazian et al. (2005) has stated that the firm with high leverage is the firm that uses the opportunity of the growth than the firm with low leverage level.

The implication of debt covenant hypothesis and under investment problem hypothesis is increasing FCF amount that is owned by company. The firm that uses high leverage will causes creditor to give the limitation in dividend policy and investment policy of company. Creditor policy controls the investment policy of motivated company to avoid: a) risk transfer 
motive from investor to creditor, and b) prosperous transfer motive from creditor to investor. One effort of creditor to avoid the motive that can loss the creditor is by pressuring manager to do not pay the dividend to investor and limiting the manager to fund the investment with high risk. There is other reason from creditor to do limitation in dividend policy and investment policy of company, i.e. to improve the firm liquidity. The research result has indicated the average of using leverage above $60 \%$ from the asset total of company. Theoretically, if the firm avoids the problem of finance, so the maximum limitation of leverage using is $50 \%$. If the firm has failed to fulfill the obligation in leverage using, so the firm can fulfill the obligation by using assets that are owned by company. The average of leverage using above $60 \%$, so it indicates the loss potential that is guaranteed by creditor is $10 \%$ if the firm has failed to fulfill the obligation. To minimize the loss, so the creditors do some steps, i.e. a) doing limitation to dividend policy and investment policy of company, b) improving the firm liquidity.

It has explained that consequence of thought from debt covenant hypothesis and under investment problem hypothesis is increasing FCF amount that has been owned by company but it cases other consequence. Theoretically, it is the thought of free cash hypothesis (Jensen, 1986). The firm that has high FCF will cause over investment problem and agency problem. Based on this explanation, it is known as indication of consequence that against the thought of free cash flow hypothesis. The thought of debt covenant hypothesis and under investment problem hypothesis indicates that creditor effort to improving FCF of company with the aim to minimize the loss from creditor and improving the ability of company to fulfill the obligation on the using of leverage. In the other hand, that thought express to reduce agency problem because existing of FCF, so the firm distributes FCF to the investor in dividend. It causes contradiction which is in the side of high leverage using can reduce agency cost (Easterbrook, 1984, Jensen, 1986), but on the other side, the using of high leverage can reduce the firm ability to pay dividend (Kalay, 1982). Easterbrook (1984) expressed that leverage can be used as substitution from dividend to reduce agency cost. Based on this explanation, it is known that that thought can make worse the agency problem between manager and investor.

Related to firm value, the research result gives the contribution to study in the thought of debt covenant, and under investment problem hypothesis, that are explained in figure 3.

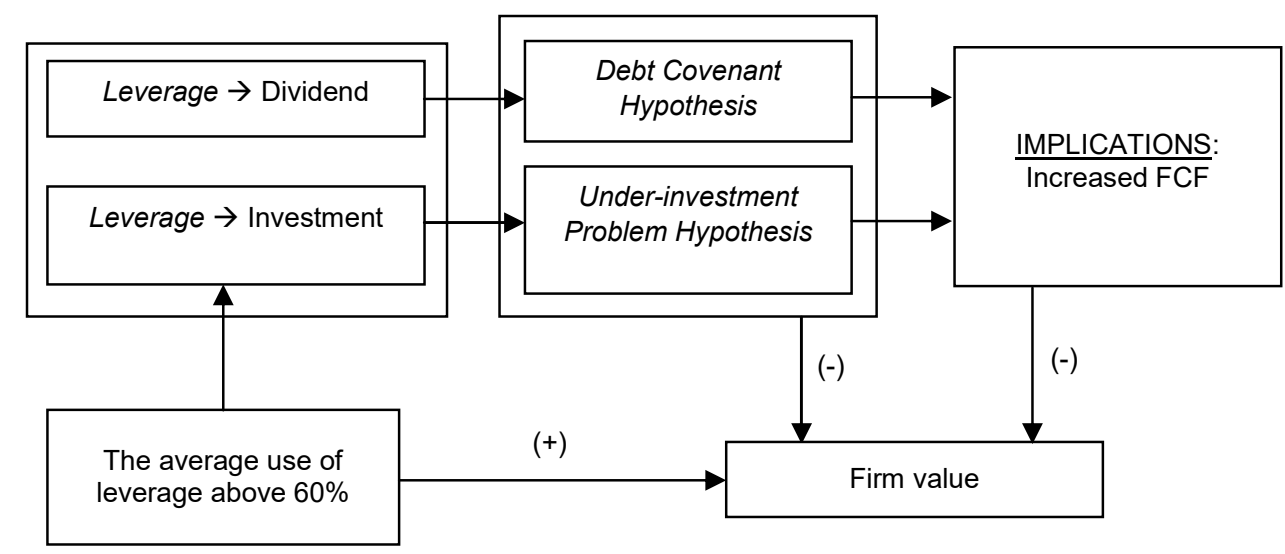

Figure 3 - Contributions Study on Debt Covenant Hypothesis and Under-investment Problem Hypothesis into Firm Value

Argumentations can be explained in figure 3 as followed:

In the section before, it is explained the consequence of thought of debt covenant hypothesis and under investment problem hypothesis, are the improving of FCF that has been owned by the firm. The research result has found the firm indication that has high FCF will causes the decreasing of firm value. Theoretically, the firm that has high FCF will cause over investment problem and finally happening agency problem. The firm that has high FCF 
indicates the attention of manager as the investor agent in firm value. According to Uyara and Tuasikal (2003), if the manager specialized the prosperity of investor, i.e. by distributing FCF in dividend form to the investor so it causes market and investor perceive positively on this policy. The same opinion by Fuller and Thakor (2002) stated that the dividend payment may give information about how the firm management uses the balance of company in the future. The thought by Uyara and Tuasikal (2003), Fuller and Thakor (2002) has strengthened the thought of dividend signaling theory (Bhattacharrya, 1979). The firm that has high FCF has given the sign or information that the firm has the potential to happen over investment problem and agency problem, so it will has negative effect on firm value.

The research results the firm indication that uses high leverage will causes the increasing of firm value. Theoretically, the research result has strengthened of thought by Ross (1977) that stated firm value will increase with the using of high leverage because of its using will increase the perception of market to the firm value. The thought of Ross (1977) is strengthened by some ideas and researches as followed:

1. Leverage can be used as mechanism to control and supervise the manager action of company (Easterbook, 1984, Jensen, 1986)

2. Leverage can improve the firm value because of the tax protection

3. The firm that uses high leverage, it describes that the firm has high growth (Titman and Wessels, 1988; Baskin, 1989; Chang and Rhee, 1990; Ozkan, 2001; Sayýlgan et al., 2006; Ni and Yu, 2008; Abor and Biekpe, 2009; Qian et al., 2009; Crnigoj and Mramor, 2009)

4. The firm that uses high leverage, it describes that the firm has low risk (Jensen et al., 1992; Moh'd et al., 1998; Ooi, 1999; Chen and Steiner, 1999; Crutchley et al., 1999; Low and Chen, 2004; Al-Najjar and Taylor, 2008; Morri and Cristanziani, 2009).

Based on the explanation before, it is known that the existing of differences of thought between dividend signaling theory (Bhattacharya, 1979) and the thought of Ross (1977) even though both ideas are basically on information asymmetry. If this research is combined with both ideas, it will be known two patterns used by company to improve the firm value, i.e. a) by using high leverage, and b) by dividend payment, even the firm cannot use both patterns alike due to both patterns have the characteristic of substitution (trade-off).

Cash flow signaling hypothesis. The result of the research found that the profitability indication has the important role in deciding the dividend policy of company so the research strengthens the thought from cash flow signaling hypothesis. The result of research also gives the contribution in the study of thought from cash flow signaling hypothesis, which is explained in figure 4.

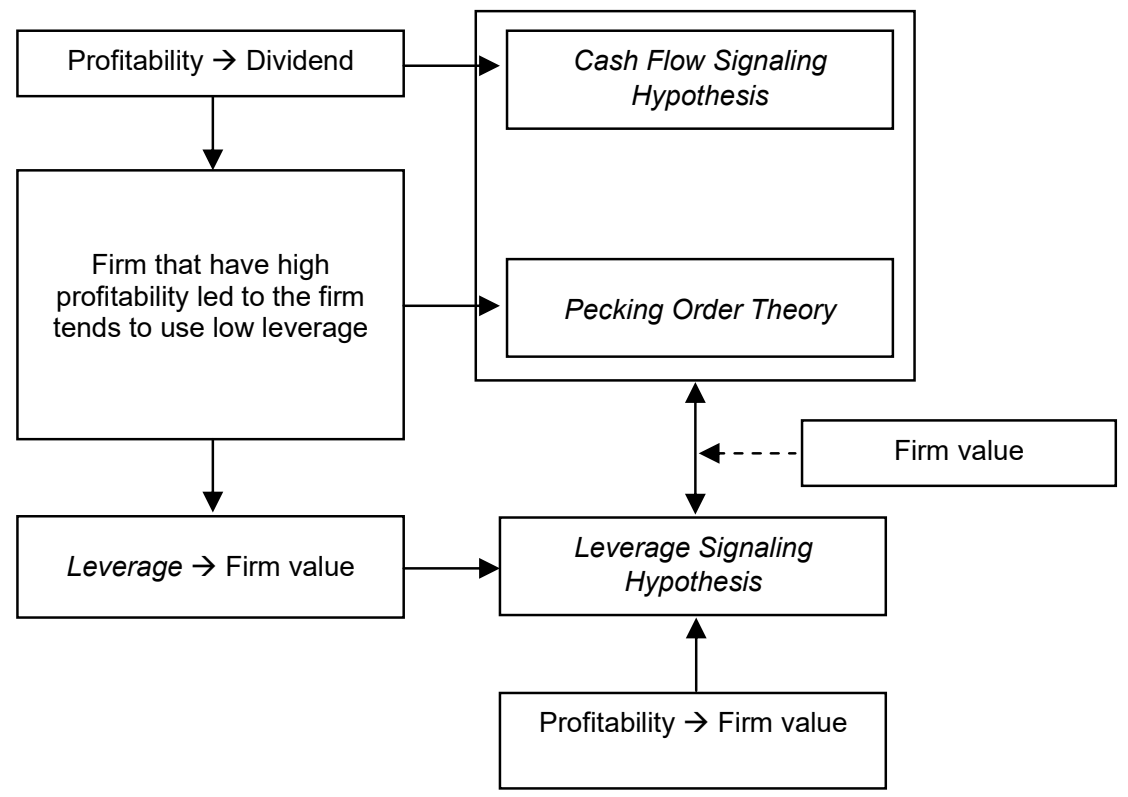

Figure 4 - Contributions Study on Cash Flow Signaling Hypothesis into Firm Value 
Argumentation that can explain figure 4 as followed:

The research result has found the evidence of company that pay the dividend is the firm that has high profitability, so that the result of research has strengthened the thought of cash flow signaling hypothesis. The thought of cash flow signaling hypothesis has given signal for the market that the firm has availability of high balance, so it is probably the investor to get dividend. Theoretically (dividend signaling theory), the firm that pays dividend will increase the firm value.

The firm that has high profitability will cause the firm tends to specialize the firm source. This argumentation is strengthened by research result to find indication of company that has high profitability which the firm that uses low leverage. This condition is appropriate with the thought pecking order theory. The other effect of pecking order theory is the firm has the wideness in dividend policy (debt covenant hypothesis) and investment policy (under investment problem hypothesis). Related to the firm value, the research result decides the firm indication that pays dividend and fund investment in high amount is the firm that has high firm value. Besides that, the effect of thought from pecking order theory also describes the firm will get low loss. The firm that gets low loss is probably that company has high firm value.

The research result has found that the firm indication that has high profitability and using low leverage is the firm that has low firm value. Theoretically, the research result found that the indication of the thought Cash flow signaling hypothesis and pecking order theory is not alike to the thought leverage signaling hypothesis.

Dividend signaling model. The research result decides the indication of dividend has the important role to improve the firm value, so that this research strengthens the ideas dividend signaling model. The research result also gives the contribution on the ideas of dividend signaling model that is explained in figure 5 .

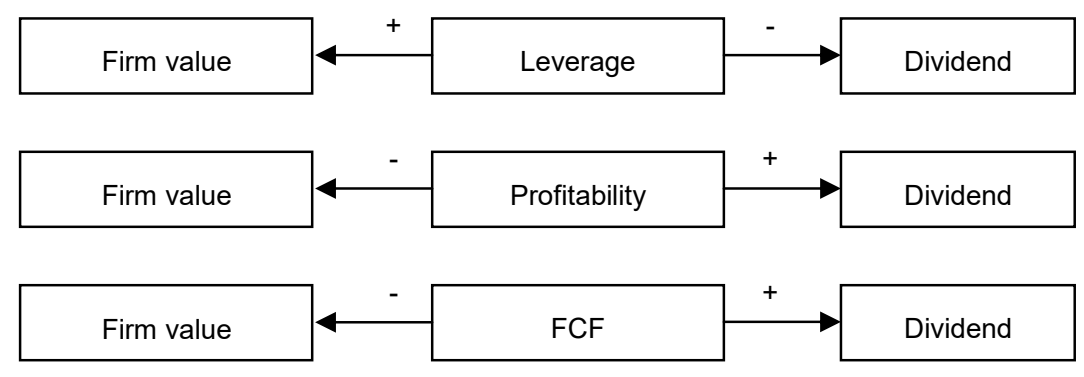

Figure 5 - Contributions Study on Dividend Signaling Model into Firm Values

Based on figure 5 can be known that indication of inconsistency of influence the fund sources (leverage, profitability, FCF) to the dividend and the firm value. Concerning to the thought of dividend signaling model, so the result strengthen the critics of the thought dividend signaling model that has been explained before. There are inconsistency of influence of fund source (leverage, profitability, FCF) to the dividend and firm value. Firstly, the result of research found the indication of company uses high leverage will cause the decreasing the firm ability to pay dividend (to strengthen debt covenant hypothesis), nut on the other hand the research result also found the indication of company that uses high leverage will cause the increasing of firm value (to strengthen leverage hypothesis). Secondly, the research result found the firm indication that has low profitability will cause the increasing the firm value. Theoretically (pecking order theory), the firm that has limitation in internal finance, it will tend to use leverage. Thirdly, the research result found the indication that has low FCF will cause the decreasing the firm ability to pay dividend (to strengthen fee cash flow hypothesis), but on the other hand the result of research also found the indication of company that has low FCF will cause the increasing the firm value. Based on the explanation before, so the result is doubted the validity of information that is delivered through dividend payment due to the factors that influence dividend payment, having the vary effect to the firm value. 
Agency theory. In the condition of companies in Indonesia, the thought of agency theory from Jensen and Meckling (1976) cannot do. Sudarma (2004) mentioned the condition of agency theory in Indonesia is the illusion. There is argumentation that explains this condition which the research result from Claessens, Djankov, Fan and Lang (1999a,b,c) found that indication of companies in Indonesia, have the ownership structure by family. The research result does not strengthen the ideas from Jensen and Meckling (1976) that expresses the manager of company prefer to use the profit of company to fund investment while the investor to prefer the dividend.

In condition manufactured company that is go public in Indonesia, is a way to improve the supervising to the manager action through the improving ownership of foreign money. In ownership security that is concentrated and controlled by certain family so the investor of foreign institution has the important role to act under the supervision of management action of company. The research has indicated the firm that has the ownership of the security in foreign institution that has high firm value. Khanna and Palepu (1999) did the research in the companies in India, had found the evidence: a) the investor of foreign institution had the influence significantly with the positive relation to the firm value, and b) the domestic investor has the influence significantly to the negative relation and firm value (tobin q). Wei et al. (2005) also found the ownership evidence had the significant influence with the firm value (tobin q). The implications of agency theory is the higher the institutional ownership of foreign investors in the ownership structure in Indonesia, then allow the enactment of agency theory proposed by Jensen and Meckling (1976).

Monitoring hypothesis. There are consequenceof thought by Easterbrook (1984) as followed:

Leverage can substitute the role from dividend to decrease agency cost. Implication of this consequence is the creditor has the importance to the whole action of company manager. The importance of creditor that causes the controlling to the manager of company as follows: a) guarantee the commitment from company manager to pay the credit of debt and the interest, and b) controlling the manager action to do action to invest with high risk.

Leverage can substitute the role of dividend to decrease the agency cost, has caused the investor encourages the manager to use the debt in the effort to a) decreasing agency cost by investors, b) there is a motive of investor to avoid the risk of investor to the creditor and finally happening prosperous transfer from creditor to the investor.

Argumentation that stated the investor encourages the manager to use leverage has been strengthened by the research Crutchley et al. (1999); Howell and Stover (2002); Joher et al. (2006); Al-Najjar and Taylor (2008), that found the evidence of institution security that has the influence significantly with the positive relation to the leverage. Mehran (1992) found that evidence of ownership has the influence not significantly with the positive relation to the debt in long time.

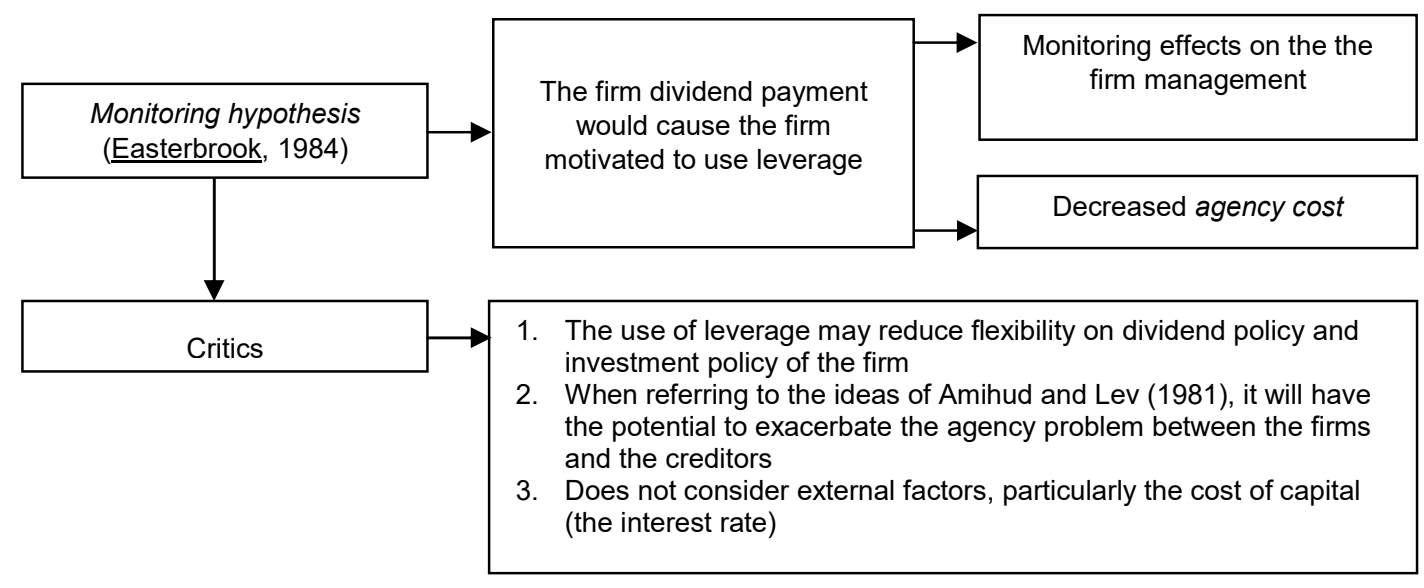

Figure 6 - Consequences of monitoring hypothesis (Easterbrook, 1984) 
The ideas from Easterbrook (1984) is the alternative to solve the problem to decrease agency cost by investor, even in the same condition it will happen new problem. Figure 6 explains about new problem that is probably happened from Easterbrook (1984)

The argumentation that explains figure 6 is followed:

The use of high leverage will give the consequence is the creditor that has the control device stronger than the manager and the investor I dividend policy and investment policy of company (Aivazian et al., 2005). The consequence of argumentation from Aivazian et al. (2005) is the management of company cannot use the opportunity of its growth. This problem is mentioned as under investment problem. As the main reason of creditor is doing the controlling to the firm management, such as a) assuring the management to be able pay leverage and its interest, b) preventing to transfer between the creditor to the investor, and c) preventing to transfer the risk from the management and investor to the creditor. The argumentation from Aivazian et al. (2005) is strengthened by the researcher that found: a) leverage has the significant influence with the negative relation to the investment, b) tobin $q$ has significant influence to the positive relation in investment. The research that is agreed with Aivazian et al. (2005) are Bradley et al. (1984); Crutchley and Hansen (1989), Sharma et al. (2003) found that the evidence of advertising and the cost of R\&D has the significant influence with the negative relation to the debt. Nini et al. (2009) also found the indication is $32 \%$ from private credit agreement between the bank side and company, contains the requirements (restrictions) in firms capital expenditures. The consequence of using high leverage is not considered by Easterbrook (1984).

If pointing at the thought from Amihud and Lev (1981) that causes the indication of investor will give the compensation for manager if the manager uses leverage to fund the firm investment. So it will make a worse of agency problem between manager and creditor. To avoid this, the thought of debt covenant hypothesis (Kalay, 1982), so the creditor effort to prevent: a) risk transfer motive from investor to creditor, b) prosperous transfer motive from creditor to investor. Abor and Biekpe (2009) found the evidence risk has the influence not significantly with the negative relation to the debt in long time. Jensen et al. (1992); Moh'd et al. (1998); Chen and Steiner (1999); Ooi (1999); Crutchley et al. (1999); Low and Chen (2004); Al-Najjar and taylor (2008), found that the risk has the influence significantly with the negative relation to leverage.

According to Chen and Steiner (1999), this condition and if the manager has the ownership of security in the firm, so that a) an increase in the ownership of the number of shares of the firm will solve agency problem between the manager and shareholders, and b) this condition will make a worse agency problem between shareholders and creditor. Cheng and Shiu (2007) also expressed based on static trade off model, it can be predicted if the firm that has the high risk on business will use the debt with low rate to fund the project of firm investment. According to Cheng and Shiu (2007), this condition because of the firm has the high risk will improve the probability of failure to pay debt and then improving the cost of financial difficulties.

The ideas of Easterbrook (1984) did not consider external factors. Related to leverage, external factor that has strong influence is interest. The higher of using, the higher of interest that is guaranteed by company. The higher interest will cause the higher o interest that is guaranteed by company. The firm that uses leverage in high rate will has any consequences, such as a) the higher interest will give the negative impact in company profitability, b) the increasing risk of the firm failure, and c) creditor has strong control device than the manager and the investor in dividend policy and investment policy of company.

Free cash flow hypothesis. The result of research gives the study contribution in the thought of free cash flow hypothesis that is explained in figure 7.

Argumentations that can explain figure 7 as followed:

The research finding found that the firm indication that has low FCF will cause the firm has no good ability to pay dividend, so that the research result strengthen the thought of free cash flow hypothesis.

The result of this research found the indication of the firm that has low FCF is the firm that uses high leverage. The result of this research strengthen the thought of free cash flow 
hypothesis. The consequence of the firm that has the characteristics: a) having low FCF, b) using high leverage is the firm has no good ability to pay dividend.

As the whole, the result of the research strengthen the thought of free cash flow hypothesis in the matter a) dividend payment and the using of high leverage has the ability to decrease FCF, b) the dividend payment and the using of high leverage have the characteristic of substitution (trade-off) to decrease FCF that has been owned by company.

Related to the firm value, the characteristic of trade-off between dividend and leverage in its role to decrease FCF, it also causes different impacts to the firm value. This argumentation has been explained in figure 2 and figure 3 .

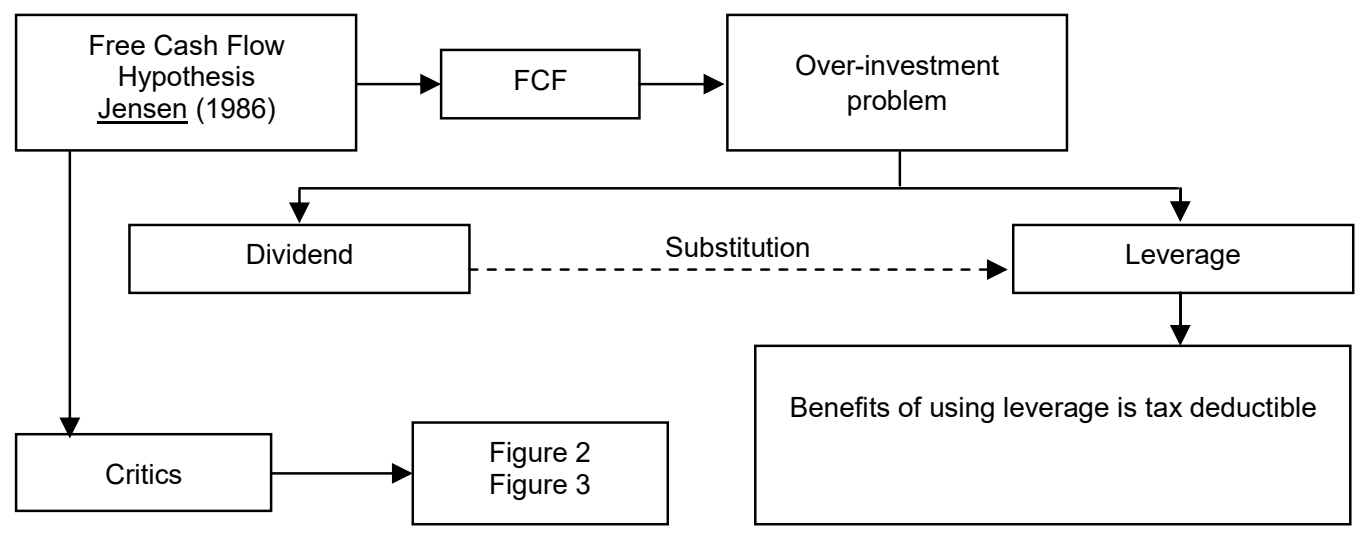

Figure 7 - Contributions Study on Free Cash Flow Hypothesis

Dividend Irrelevance Theory $(M M)$. The research result found that dividend and investment indication have the influence significantly to the firm value, so the result does not strengthen dividend irrelevance theory (MM). Besides that, the dividend regression of coefficient to the firm value is $39 \%$ that is higher investment regression coefficient to the firm value $(16.7 \%)$. It indicates some things, i.e.:

Manager and investor guess that dividend and investment as the important factor to make firm value;

Dividend is the important factor than the investment to make firm value. It is due to some reason, as followed:

The low dividend that is paid by the firm for 5 years (33\%), that has indicated a) in general, the firm paying dividends inconsistently or not paying dividends, b) payment of dividends is not something that is annually held by the firm. When the firm has paid dividend, the trading commodities will respond positively to the firm security. It is due to the strong perception of investor that the firm which pays dividend is the firm that has good ability;

A market guess the investment is routine activity that is undertaken by company, so the investment has the ability under dividend to make firm value. Generally, the market will guess on a) the firm that newly invests, b) the firm that do acquisition or acquired, and c) the firm that do merger.

Pecking Order Theory. The result of research gives the contribution on the thought of pecking order theory, that will be explained in figure 8 .

Argumentations that can be explained on figure 8 as followed:

The result of research found the indication of company that uses low leverage is the firm that has good profitability or the firm tends to emphasize the internal monetary source than external fund source. Based on the result, the consequences of company that uses low leverage are: a) the firm has the ability to maximize the fund of investment (strengthening under investment problem hypothesis), and c) the firm that pay dividend and fund the high investment will increase the firm value (strengthening the dividend signaling model and irrelevance dividend theory)

The result of research also found the indication of company that uses low leverage will cause the firm value is low (strengthening leverage signaling hypothesis) 
Figure 8 has indicated the thought of pecking order theory and leverage signaling hypothesis has the different impact to the firm value. The controversy is due to the difference of point of view that the using of leverage may not over the firm capital. The aim is to control the dividend policy and investment policy of company are stronger than creditor. It is different with the thought before, the thought of leverage signaling hypothesis views the firm uses high leverage will give information to the market that the firm has the opportunity of growth well. So it is expected to the firm will has high profitability in the future.

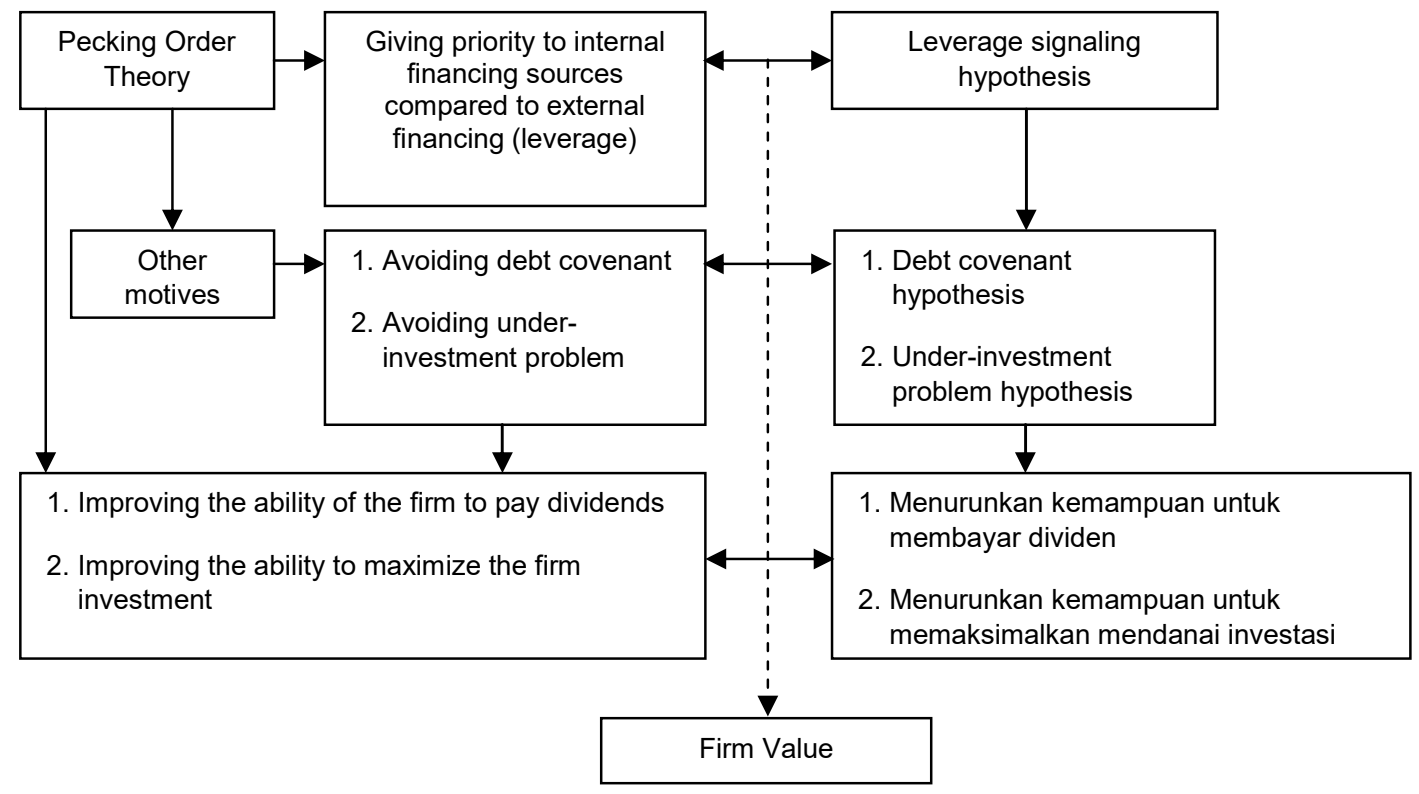

Figure 8 - Contributions Study on Pecking Order Theory

The controversy of both ideas is happened because of the limitation on dividend and investment policy to the firm that uses high leverage. It is conducted by creditor to prevent the motives a) prosperous transfer from creditor to the investors, and b) risk transfer from the investor to creditor. The investor and monetary market tend to give positive reaction to the firm that uses high leverage (prosperous transfer motive from creditor to investors). While the creditor attempts to minimize the loss that is happened because giving the leverage aid to the firm (preventing risk transfer motive from the investor to creditor). Based on the explanation, it is known the indication that the tendency from company manager whether tend to choose pecking order theory or leverage signaling hypothesis will has different impact to the pattern taken by companies to improve the firm value, i.e. a) the firm uses high leverage, b) the firm uses low leverage in order to the firm can pay dividend and fund the investment in high rate.

\section{REFERENCES}

1. Abor, J., Biekpe, N. (2009). How do we explain the capital structure of SME's in subSaharan Africa?. Journal of Economic Studies, 36(1): 83-97.

2. Adaoglu, C. (2000). Instability in the Dividend Policy of the Istanbul Stock Exchange (ISE) Corporations: Evidence From An Emerging Market. Emerging Markets Review, 1: 252-270.

3. Adedeji, A. (1998). Does the Pecking Order Hypothesis Explain the Dividend Payout Ratios of Firms in the UK?. Journal of Business Finance \& Accounting, 25(9-10): 11271155.

4. Aivazian, V.A., Ge, Y., Qiu, J. (2005). The impact of leverage on firm investment: Canadian evidence. Journal of Corporate Finance, 11: 277-291. 
5. Aivazian, V., Booth, L., Cleary, S. (2003a). Dividend Policy and the Organization of Capital Markets. Journal of Multinational Financial Management, 13: 101-121.

6. Aivazian, V., Booth, L., Cleary, S. (2003b). Do Emerging Market Firms Follow Different Dividend Policies From U.S. Firms?. The Journal of Financial Research, Vol. XXVI(3): 371-387

7. Allen, Dave E. and Veronica S. Rachim. 1996. Dividend policy and stock price volatility: Australian evidence. Applied Financial Economics, Vol. 6, pp. 175-188

8. Al-Najjar, B., Taylor, P. (2008). The relationship between capital structure and ownership structure: New evidence from Jordanian panel data. Managerial Finance, Vol. 34, No. 12, pp. 919-933

9. Amihud, Y., Lev, B. (1981). Risk Reduction as a Managerial Motive for Conglomerate Mergers. The Bell Journal of Economics, Vol. 12, No. 2, pp. 605-617

10. Ammar, A.I. (2001). Profitability of electrical contractors using financial and economical data: The effect of company's size. Unpublished Dissertation. University of WisconsinMadison

11. Barker, R.G. (1999). Survey and Market-Based Evidence of Industry-Dependence in Analysts' Preferences Between the Dividend Yield and Price-Earnings Ratio Valuation Models. Journal of Business Finance \& Accounting, 26(3-4): 393-418.

12. Barnes, Michelle, Boyd, J.H., Smith, B.D. (1999). Theories of Money, Credit and Aggregate Economic Activity: Inflation and asset returns. European Economic Review, 43: 737-754.

13. Baskin, J. (1989). An Empirical Investigation of the Pecking Order Hypothesis. Financial Management, 18(1): 26-35.

14. Benartzi, Shlomo, Michaely, R., Thaler, R. (1997). Do Changes in Dividends Signal the Future or the Past?. The Journal of Finance, 52(3): 1007-1034.

15. Bhattacharya, S. (1979). Imperfect Information, Dividend Policy, and "the Bird in the Hand" Fallacy. The Bell Journal of Economics, 10(1): 259-270.

16. Bhattacharyya, N. (2007). Dividend Policy: A Review. Managerial Finance, 33(1): 4-13.

17. Black, F. (1976). The Dividend Puzzle. Journal of Portfolio Management, 2: 5-8.

18. Blau, B.M., Fuller, K.P. (2008). Flexibility and Dividends. Journal of Corporate Finance, 14: 133-152.

19. Bleaney, M.F. (1996). Macroeconomic stability, investment and growth in developing countries. Journal of Development Economics, 48: 461-477.

20. Borde, S.F., Byrd, A.K., Atkinson, S.M. (1999). Stock Price Reaction to Dividend Increases in the Hotel and Restaurant Sector. Journal of Hospitality and Tourism Research, 23(1): 40-52.

21. Bortz, G.A., Rust, J.P. (1984). Why Do Companies Pay Dividends? Comment. The American Economic Review, 74(5): 1135-1136.

22. Bradley, Michael, Jarrell, G.A., Kim, E.H. (1984). On the existence of an optimal capital structure: Theory and evidence. The Journal of Finance, Vol. XXXIX(3): 857-880.

23. Brav, Alon, Graham, J.R., Harvey, C.R., Michaely, R. (2005). Payout Policy in the 21st Century. Journal of Financial Economics, 77: 483-527.

24. Brealey, R.A., Myers S.C. (1991). Principle of corporate finance. Fourth edition. McGrawHill

25. Brigham, E.F. (1995). Fundamentals of financial management. Seventh Edition. The Dryden Press

26. Brown, Philip, How, J.C.Y., Verhoeven, P. (2008). The accuracy of analysts dividend forecasts around the world. Pacific-Basin Finance Journal, 16: 411-435.

27. Bulan, Laarni, Subramanian, N., Tanlu, L. (2007). On the Timing of Dividend Initiations. Financial Management, 36(4): 31-65.

28. Chang, R.P., Rhee, S.G. (1990). The Impact of Personal Taxes on Corporate Dividend Policy and Capital Structure Decisions. Financial Management, 19(2): 21-31.

29. Chen, C.R., Steiner, T.L. (1999). Managerial Ownership and Agency Conflicts: A Nonlinear Simultaneous Equation Analysis of Managerial Ownership, Risk Taking, Debt Policy, and Dividend Policy. The Financial Review, 34: 119-136. 
30. Chen, S.S., Ho, K.W. (2000). Corporate Diversification, Ownership Structure, and Firm Value: The Singapore Evidence. International Review of Financial Analysis. 9: 315326.

31. Cheng, S.R., Shiu, C.Y. (2007). Investor protection and capital structure: International evidence. Journal of Multinational Financial Management, 17: 30-44.

32. Cho, M.H. (1998). Ownership structure, investment, and the corporate value: an empirical analysis. Journal of Financial Economics, 47: 103-121.

33. Claessens, Stijn, Djankov, S., Fan, J.P.H., Lang, L.P.H. (1999a). Who Control East Asian Corporation. Policy Research Working Paper, The World Bank, Financial Sector Practice Department, Financial Economics Unit.

34. Claessens, Stijn, Djankov, S., Fan, J.P.H., Lang, L.P.H. (1999b). Corporate Diversification in East Asia. Policy Research Working Paper, The World Bank, Financial Sector Practice Department, Financial Economics Unit.

35. Claessens, Stijn, Djankov, S., Fan, J.P.H., Lang, L.P.H. (1999c). Expropriation of Minority Shareholders. Policy Research Working Paper, The World Bank, Financial Sector Practice Department, Financial Economics Unit.

36. Connolly, R.A., Hirschey, M. (2005). Firm size and the effect of R\&D on Tobin's q. R\&D Management, 35(2): 217-223.

37. Conroy, R.M., Eades, K.M., Harris, R.S. (2000). A Test of the Relative Pricing Effects of Dividends and Earnings: Evidence From Simultaneous Announcements in Japan. The Journal of Finance, LV(3): 1199-1227.

38. Crnigoj, M., Mramor, D. (2009). Determinants of Capital Structure in Emerging European Economies: Evidence from Slovenian Firms. Emerging Markets Finance \& Trade, 45(1): 72-89.

39. Crutchley, C.E., Hansen, R.S. (1989). A Test of the Agency Theory of Managerial Ownership, Corporate Leverage, and Corporate Dividends. Financial Management, 18(4): 36-46.

40. Crutchley, C.E., Jensen, M.R.H., Jahera, J.S., Raymond, J.E. (1999). Agency problems and the simultaneity of financial decision making: The role of institutional ownership. International Review of Financial Analysis, 8(2): 177-197.

41. DeAngelo, H., DeAngelo, L., Skinner, D.J. (2000). Special dividends and the evolution of dividend signaling. Journal of Financial Economics, 57: 309-354.

42. DeAngelo, H., DeAngelo, L., Stulz, R.M. (2006). Dividend Policy and the Earned/Contributed Capital Mix: A Test of the Life-Cycle Theory. Journal of Financial Economics, 81: 227-254.

43. Del Brio, E., De Miguel, A., Pindado, J. (2003). Investment and firm value: an analysis using panel data. Applied Financial Economics, 13: 913-923.

44. Denis, D.J., Osobov, I. (2008). Why Do Firms Pay Dividends? International Evidence on the Determinants of Dividend Policy. Journal of Financial Economics, 89: 62- 82.

45. Dhrymes, P.J., Kurz, M. (1967). Investment, Dividend, and External Finance Behavior of Firms. in Ferber R. (Ed.), Determinants of Investment Behavior: A Conference of the Universities-National Bureau Committee For Economic Research. National Bureau of Economic Research, New York.

46. Doukas, J.A., Pantzalis, C. (2003). Geographic diversification and agency costs of debt of multinational firms. Journal of Corporate Finance, 9: 59-92.

47. Dunham, L.M. (2008). The Dynamic Relation Among Investment, Earnings and Dividends. Unpublished Dissertation. University of Nebraska

48. Easterbrook, F.H. (1984). Two Agency-Cost Explanations of Dividends. The American Economic Review, 74(4): 650-659.

49. Elder, J. (2004). Another Perspective on the Effects of Inflation Uncertainty. Journal of Money, Credit and Banking, 36(5): 911-928.

50. Elston, J.A. (1996). Dividend Policy and Investment: Theory and Evidence From US Panel Data. Managerial and Decision Economics, 17(3): 267-276.

51. Fama, E.F., French, K.R., (2001). Disappearing dividends: changing firm characteristics or lower propensity to pay?. Journal of Financial Economics. 60: 3-43 
52. Fan, Joseph, P.H., Huang, J., Oberholzer-Gee, F., Smith, T.D., Zhao, M. (2008). Diversification of Chinese companies: an international comparison. Chinese Management Studies, 2(1): 6-13.

53. Feldstein, M., Green, J. (1983). Why Do Companies Pay Dividends?. The American Economic Review, 73(1): 17-30.

54. Frankfurter, G.M., Wood, B.G. Jr. (2002). Dividend Policy Theories and Their Empirical Tests. International Review of Financial Analysis, 11: 111-138.

55. Fuller, K., Thakor, A. (2002). Signalling, Free Cash Flow, and "Nonmonotonic" Dividends. Social Science Research Network. Working paper, University of Georgia.

56. Ghosh, S. (2007). Bank Monitoring, Managerial Ownership and Tobin's Q: An Empirical Analysis for India. Managerial and Decision Economics, 28: 129-143.

57. Glen, J.D., Karmokolias, Y., Miller, R.R., Shah, S. (1995). Dividend Policy and Behavior in Emerging Markets: To Pay or Not to Pay. IFC Discussion paper 26, Washington DC: International Finance Corporation.

58. Grullon, Gustavo, Michaely, R., Benartzi, S., Thaler, R.H. (2005). Dividend Changes Do Not Signal Changes in Future Profitability. Journal of Business, 78(5): 1659-1682.

59. Gugler, K. (2003). Corporate Governance, Dividend Payout Policy, and the Interrelation Between Dividends, R\&D, and Capital Investment. Journal of Banking and Finance, 27: 1297-1321.

60. Howell, J.C., Stover, R.D. (2002). How much do governance and managerial behavior matter in investment decisions? Evidence from failed thrift auctions. Journal of Corporate Finance, 8: 195-211.

61. Hu, C.X. (1999). Leverage, Monetary Policy, and Firm Investment. FRBSF Economic Review, No. 2: 32-39.

62. Hughes, J.P. 2008. R\&D and Dividend Payments As Determinants of Corporate Value in the UK. International Journal of Managerial Finance, 4(1): 76-91.

63. Jensen, G.R., Solberg, D.P., Zorn, T.S. (1992). Simultaneous Determination of Insider Ownership, Debt, and Dividend Policies. The Journal of Financial and Quantitative Analysis, 27(2): 247-263.

64. Jensen, Michael, C., Meckling, W.H. (1976). Theory of the firm: managerial behavior agency cost and ownership structure. Journal of Financial Economics, 3(4): 305-360.

65. Jensen, Michael, C., (1986). Agency Costs of Free Cash Flow, Corporate Finance and Takeovers. The American Economic Review, 76(2): 323-329.

66. Joher, Huson, Ali, M., Nazrul. (2006). The Impact Of Ownership Structure On Corporate Debt Policy: Two Stage Least Square Simultaneous Model Approach For Post Crisis Period: Evidence From Kuala Lumpur Stock Exchange. International Business \& Economics Research Journal, 5(5): 51-64.

67. Kalay, A. (1982). Stockholder-Bondholder Conflict and Dividend Constraints. Journal of Financial Economics, 10: 211-233.

68. Kandir, S.Y. (2008). Macroeconomic Variables, Firm Characteristics and Stock Returns: Evidence From Turkey. International Research Journal of Finance and Economics, 16: 35-45.

69. Kang, B.S. (2001). Essays on Corporate Dividend Policy: International Investigation at The Micro and Macro Levels. Unpublished Dissertation. The Chatolic University of America

70. Khanna, T., Palepu, K. (1999). Emerging Market Business Groups, Foreign Investors, and Corporate Governance. Working Paper 6955. National Bureau of Economic Research.

71. Landon, S., Smith, C.E. (2008). Investment and the exchange rate: Short run and long run aggregate and sector-level estimates. Journal of International Money and Finance, doi:10.1016/j.jimon.n.2008.07.009

72. Levy, H., Sarnat, M. (1994). Capital investment \& Financial Decision. Fifth Edition. Prentice-Hall 
73. López-Iturriaga, F.J., Rodríguez-Sanz, J.A. (2001). Ownership Structure, Corporate Value and Firm Investment: A Simultaneous Equations Analysis Spanish Companies. Journal of Management and Governance, 5: 179-204.

74. Low, P.Y., Chen, K.H. (2004). Diversification and capital structure: Some international evidence. Review of Quantitative and Accounting. 23(1): 55-71.

75. Mackey, TB. (2006). Essays On Corporate Diversification And Firm Value. Unpublished Dissertation. School of The Ohio State University

76. Marsh, T.A., Merton, R.C. (1987). Dividend Behavior for the Aggregate Stock Market. The Journal of Business, 60(1): 1-40.

77. McCabe, G.M. (1979). The Empirical Relationship Between Investment and Financing: A New Look. The Journal of Financial and Quantitative Analysis, 14(1): 119-135.

78. Mehran, H. 1992. Executive Incentive Plans, Corporate Control, and Capital Structure. Journal of Financial and Ouantitative Analysis, 27(4): 539-560.

79. Miller, M.H., Modigliani, F. (1961). Dividend Policy, Growth, and the Valuation of Shares. The Journal of Business, 34(4): 411-433.

80. Moh'd, M.A., Perry, L.G., Rimbey, J.N. (1998). The impact of ownership structure on corporate debt policy: A time-series cross-sectional analysis. The Financial Review, 33(3): 85.

81. Morck, R., Shleifer, A., Vishny R.W. (1988). Management Ownership and Market Valuation. Journal of Financial Economics, 20: 293-315.

82. Morri, G., Cristanziani, F. (2009). What determines the capital structure of real estate companies?. Journal of Property Investment \& Finance, 27(4): 318-372.

83. Nelson, C.R. (1976). Inflation and Rates of Return on Common Stocks. The Journal of Finance, 31(2): 471-483.

84. Ni, J., Yu, M. 2008. Testing the Pecking-Order Theory. The Chinese Economy, 41(1): 97-113.

85. Nini, G., Smith, D.C., Sufi, A. (2009). Creditor control rights and firm investment policy. Journal of Financial Economics. doi:10.1016/j.j.neco.2008.04.008

86. Ooi, J. (1999). The determinants of capital structure: Evidence on UK property companies. Journal of Property Investment \& Finance, 17(5): 464-480.

87. Ozkan, A. (2001). Determinants of Capital Structure and Adjustment to Long Run Target: Evidence from UK Company Panel Data. Joumal of Business Finance and Accounting, 28(1-2): 175-198.

88. Penman, S.H. (1983). The Predictive Content of Earnings Forecasts and Dividends. The Journal of Finance, 38(4): 1181-1199.

89. Peterson, P.P., Benesh, G.A. (1983). A Reexamination of the Empirical Relationship Between Investment and Financing Decisions. The Journal of Financial and Quantitative Analysis, 18(4): 439-453.

90. Qian, Yanmin, Tian, Y., Wirjanto, T.S. (2009). Do Chinese publicly listed companies adjust their capital structure toward a target level?. China Economic Review, doi:10.1016/j. chieco.2009.06.001

91. Rahman, N. (2006). Two Essays on Dividend Policy. Unpublished Dissertation. The Faculty of The Graduate School of Business. Illonis, Chicago.

92. Rees, W.P. (1999). Influences on the Value Relevance of Equity and Net Income in the UK. Managerial Finance, 25(12): 58-65.

93. Renneboog, L., Trojanowski, G. (2007). Control Structures and Payout Policy. Managerial Finance, 33(1): 43-64.

94. Riahi-Belkaoui, A., Picur, R.D. (2001). Investment Opportunity Set Dependence of Dividend Yield and Price Earnings Ratio. Managerial Finance, 27(3): 65-71.

95. Ross, S.A. (1977). The Determination of Financial Structure: The Incentive-Signalling Approach. The Bell Journal of Economics, 8(1): 23-40.

96. Sayýlgan, Güven, Karabacak, H., Küçükkocaoglu, G. (2006). The Firm-Specific Determinants Of Corporate Capital Structure: Evidence From Turkish Panel Data. Investment Management and Financial Innovations, 3(3): 125-139. 
97. Sharma, Jandhyala, Kamath, R., Tuluca, S. (2003). Determinants of corporate borrowing: An application of a neural network approach. American Business Review, 21(2): 63-73.

98. Stevens, J.L., Jose, M.L. (1992). The Effects of Dividend Payout, Stability, and Smoothing on Firm Value. Journal of Accounting, Auditing \& Finance, pp. 195-212.

99. Sudarma, M. 2004. Pengaruh struktur kepemilikan saham, faktor intern dan faktor ekstern terhadap struktur modal dan nilai perusahaan. Unpublished Disertasi. Program Pascasarjana Universitas Brawijaya, Malang.

100. Sulong, Z., Noor, F.M. (2008). Dividends, Ownership Structure and Board Governance on Firm Value: Empirical Evidence From Malaysian Listed Firms. Malaysian Accounting Review, 7(2): 55-94.

101. Titman, S., Wessels, R. (1988). The Determinants of Capital Structure Choice. The Journal of Finance, 43(1): 1-19.

102. Tong, Z. (2009). Firm diversification and the value of corporate cash holdings. Journal of Corporate Finance, doi:10.1016/j.jcorp.n.2009.05.001

103. Tsoukalas, D., Sil, S. (1999). The Determinants of Stock Prices: Evidence From The United Kingdom Stock Market. Management Research News, 22(5): 1-14.

104. Uyara, A.S., Tuasikal, A. (2003). Moderasi aliran kas bebas terhadap hubungan rasio pembayaran dividend an pengeluaran modal dengan earning response coefficients. Jurnal Riset Akuntansi Indonesia, 6(2): 186-198.

105. Watts, R. (1973). The Information Content of Dividends. The Journal of Business, 46(2):191-211.

106. Wei, Zuobao, Xie, F., Zhang, S. (2005). Ownership Structure and Firm Value in China's Privatized Firms: 1991-2001. Journal of Financial and Quantitative Analysis, 40(1): 87108. 